\title{
PATOGENISITAS CENDAWAN ENTOMOPATOGEN Beauveria bassiana (DEUTEROMYCOTINA: HYPHOMYCETES) PADA BERBAGAI STADIA KEPIK HIJAU (Nezara viridula L.)
}

\author{
Yusmani Prayogo \\ Balai Penelitian Tanaman Kacang-kacangan dan Umbi-umbian \\ Jl. Raya Kendalpayak KM 8, Kotak Pos 66 Malang, 65101 \\ E-mail:manik_galek@yahoo.com
}

\begin{abstract}
Pathogenicity of Beauveria bassiana Bals. Vuill. (Deuteromycotina:Hyphomycetes) on various stages of eggs and nymphs of the green stink bug (Nezara viridula $L$.). The green stink bug (Nezara viridula $L$.) is one of the important soybean podsucking bug besides brown stink bug (Riptortus linearis) and green stink bug (Piezodorus hybneri). Up to now, pest control mostlyrely on the chemical insecticides, The objectiveof this experiment was to study the pathogenicity of Beauveria bassianaon various stages of eggs and nymphs of the green stink bug. Experiment was conducted in the laboratory of Entomology, Indonesian Legumes and Tuber Crops Research Institute (ILETRI) Malang, from January to June 2011. The treatments consists of various eggs and nymphs stages of green stink bug. The results showed that $B$. bassiana was able to infect the eggs green stink bug both of the newly laid and the six days old eggs. As a results of this infection, $96 \%$ eggs did not hatched. The younger of eggs, the more susceptible to B. bassiana. The infected egg prolonged hatching periods to three days. $B$. bassianawas also toxic to all stages of the green stink bug, especially to the first and second instarswith mortality rate of 69-96\%. The nymph of third, fourth, ad fifth instar and adult stage were more tolerant to the B. bassiana infection. This study suggest that one way to control green stink bug be the use of entomopathogen B. bassiana againts their ggs or younginstar
\end{abstract}

Key words: toxicity, B. bassiana, eggs, nymphs, $N$. viridula.

\begin{abstract}
ABSTRAK
Patogenisitas cendawan entomopatogen Beauveria bassiana Bals. Vuill. (Deuteromycotina:Hyphomycetes) pada berbagai stadia kepik hijau (Nezara viridula $L$.). Kepik hijau (Nezara viridula $\mathrm{L}$.) merupakan salah satu hama pengisap polong kedelai yang penting selain kepik coklat (Riptortus linearis) dan kepik hijau pucat (Piezodorus hybneri). Teknologi pengendalian yang tersedia hanya mengandalkan efikasi insektisida kimia,namun perkembangan populasi di lapangan terus meningkat. Penelitian ini bertujuan untuk mempelajari patogenisitas cendawan entomopatogen Beauveria bassiana terhadap berbagai stadia kepik hijau. Penelitian dilakukan di laboratorium Entomologi, Balai Penelitian Tanaman Kacang-kacangan dan Umbiumbian (Balitkabi) Malang mulai bulan Januari hingga Juni 2011. Perlakuan adalah umur telur dan stadia perkembangan nimfa kepik hijau. Hasil penelitian menunjukkan bahwa cendawan B. bassiana bersifat ovisidal karena toksik terhadap telur kepik hijau. B. bassiana mampu menginfeksi telur kepik hijau, baik telur yang baru diletakkan maupun telur umur enam hari. Akibat infeksi tersebut, telur yang tidak menetas mencapai $96 \%$. Semakin muda umur telur kepik hijau, semakin rentan terhadap $B$. bassiana. Telur kepik hijau yang terinfeksi $B$. bassiana menjadi terlambat menetas selama tiga hari. Cendawan $B$. bassiana juga toksik terhadap semua stadia nimfa kepik hijau, terutamanimfa I dan II dengan mortalitas berkisar 69-96\%. Nimfa III, IV, V dan imago kepik hijau lebih toleran terhadap $B$. bassiana dibandingkan nimfa I dan II. Untuk menekan perkembangan populasi kepik hijau maka dianjurkan aplikasi menggunakan cendawan B. bassiana pada stadia telur atau nimfa stadia awal.
\end{abstract}

Kata kunci:toksisitas, B. bassiana, telur, nimfa, $N$. viridula.

\section{PENDAHULUAN}

Hama pengisap polong kedelai terdiri tiga jenis yaitu: kepik coklat (Riptortus linearis), kepik hijau (Nezara viridula), dan kepik hijau pucat (Piezodorus hybneri). Kepik hijau termasuk dalam famili Pentatomidae dan ordo Hemiptera, merupakan hama pengisap polong yang sangat penting dan penyebarannya lebih luas dibandingkan $R$. linearis maupun $P$. hybneri (Ehler, 2002; Jones \& Westcot, 2002; Knight \& Gurr, 2007; Prado et al., 2009). Hama ini memiliki tanaman inang yang cukup luas meliputi tanaman pangan, buahbuahan, hias, sayuran bahkan beberapa jenis gulma (Panizzi et al., 2000a; Mau \& Kessing, 2007). Kepik 
hijau datang pertama kali di lahan pertanaman kedelai pada umur kurang lebih 35 hari setelah tanam (HST), pada waktutersebut imago bertujuan untuk meletakkan telur pada permukaan daun (Correa-Ferreira \& Azenvedo, 2002; Fortes et al., 2006; Vivan \& Panizzi, 2006).

Menurut Fortes et al.(2006) seekor imago betina kepik hijau mampu menghasilkan telur berkisar 104-470 butir yang diletakkan secara berkelompok pada permukaan daun bagian atas maupun bawah. Tiapkelompok telur terdiri dari 10-50 butir. Telur akan menetas kurang lebih enam hingga tujuh hari setelah diletakkan imago (Panizzi et al., 2000b; Gonzalez \& Ferrero, 2008). Setelah telur menetas maka terbentuk nimfa I yang berlangsung selama lima sampai enam hari sebelum berganti kulit (moulting) menjadi nimfa II (Noda \& Kamano, 2002; Vivan \& Panizzi, 2005; Gonzalez \& Ferrero, 2008). Nimfa II juga berlangsung kurang lebih enam hari, sedangkan nimfa III dan IV hanya berlangsung selama lima hari. Stadia nimfa V juga berlangsung lima hari sebelum berkembang menjadi imago (Panizzi et al., 2000a; Noda \& Kamano, 2002; Fortes et al., 2006). Sedangkan siklus hidup kepik hijau mulai telur hingga terbentuk imago berlangsung selama 31-76 hari (Gonzalez \&Ferrero, 2008). Stadia nimfa maupun imago mempunyai peluang yang sama besarnya dalam menyebabkan kerusakan polong kedelai. Kehilangan hasil akibat serangan kepik hijau hingga mencapai 80\% (Correa-Ferreira \& Azevedo, 2002).

Teknologi pengendalian yang dilakukan oleh petani adalah aplikasi insektisida kimia (Emfinger $e t$ al., 2001; Greene et al., 2003; Willrich et al., 2003; Tillman, 2006). Namun populasi kepik hijau di lapangan masih menjadi masalah karena perkembangan hama tersebut semakin meningkat dari musim ke musim. Fenomena ini terjadi karena aplikasi insektisida kimia hanya mampu membunuh stadia nimfa maupun imago. Sementara itu, stadia telur masih mampu bertahan dan berkembang terus karena belum ditemukan senyawa insekltisida kimia yang mampu menggagalkan penetasan telur. Selain itu, aplikasi insektisida kimia membunuh hampir semua jenis serangga berguna, baik predator maupun parasitoid (Studebaker \& Kring, 2003; Kim et al., 2006; Rogers et al., 2007; Echegaray, 2009; Cloyd \& Bethke, 2010). Tersedianya inang di lapangan terus menerus dan banyaknya jenis inang juga menjadi salah satu faktor peningkatan populasi kepik hijau. Oleh karena itu, strategi pengendalian perlu ditekankan untuk mengatasi kondisi perkembangan hama tersebut agar populasinya hanya berada di bawah ambang ekonomi yaitu dengan menerapkan pengelolaan berbagai agens hayati (ElHusseini et al., 2006; Knight \& Gurr, 2007).
Cendawan entomopatogen Beauveria bassiana dilaporkan mampu menginfeksi berbagai jenis hama dari beberapa ordo (Dhuyo \& Ahmad, 2007; LozanoGutierrez \& Espana-Luna, 2008; Tamuli \& Gurusubramanium, 2011). Cendawan ini mengandung toksin yang sangat toksik terhadap serangga sasaran hanya dalam rentang waktu yang cukup pendek berkisar 3-5 hari setelah aplikasi (Lozano-Guiterrez \& EspanaLuna, 2008; Trizelia \& Nurdin, 2010). Kelebihan cendawan tersebut karena mampu menginfeksi berbagai stadia serangga termasuk larva maupun imago (James et al., 2003). Sementara itu, informasi toksisitas cendawan $B$. bassiana terhadap telur maupun nimfa kepik hijau belum banyak dilaporkan. Penelitian ini bertujuan untuk mempelajari toksisitas cendawan entomopatogen B.bassiana dalam mengendalikan berbagai stadia kepik hijau.

\section{METODE PENELITIAN}

Penelitian dilakukan di Laboratorium Entomologi, Balai Penelitian Tanaman Kacangkacangan dan Umbi-umbian (Balitkabi) Malang, mulai bulan Januari sampai dengan Juni 2011. Penelitian menggunakan rancangan acak lengkap (RAL), ulangan sebanyak lima kali. Penelitian terdiri dari dua tahap yaitu

\section{Uji Toksisitas Cendawan B. bassiana terhadap} Telur Kepik Hijau. Perlakuan adalah berbagai umur telur yaitu; (1) 0 hari (baru diletakkan imago), (2) umur 1 hari setelah diletakkan imago, (3) umur 2 hari setelah diletakkan imago, (4) umur 3 hari setelah diletakkan imago, (5) umur 4 hari setelah diletakkan imago, (6) umur 5 hari setelah diletakkan imago, (7) umur 6 hari setelah diletakkan imago, dan (8) kontrol (telur umur 0 hari tanpa aplikasi). Jumlah telur yang diuji pada tiap ulangan sebanyak 25 butir tiap perlakuan, sehingga total telur yang digunakan pada setiap perlakuan sebanyak 125 butir. Masing-masing umur telur yang diuji diupayakan seragam pada tiap ulangan untuk menghindari terjadinya keragaman.

\section{Uji Toksisitas Cendawan B. bassiana terhadap} Stadia Nimfa Kepik Hijau. Perlakuan adalah berbagai stadia nimfa yaitu; (1) nimfa instar I, (2) nimfa instar II, (3) nimfa instar III, (4) nimfa instar IV, (5) nimfa instar $\mathrm{V}$, dan (6) imago. Jumlah serangga yang diuji pada masing-masing stadia sebanyak 25 ekor tiap ulangan sehingga total serangga yang digunakan setiap perlakuan sebanyak 125 ekor. Umur serangga pada tiap ulangan diupayakan seragam untuk menghindari terjadinya 
keragaman. Nimfa yang digunakan sebagai serangga uji dalam penelitian ini adalah generasi F2.

\section{Perkembangbiakan Serangga Kepik Hijau.} Kelompok telur, nimfa maupun imago kepik hijau diperoleh dari lahan pertanaman kedelai di kebun percobaan (KP) Kendalpayak pada bulan Oktober 2010. Kelompok telur yang diperoleh dari lapangan kemudian dikumpulkan dan dimasukkan ke dalam kotak plastik yang di dalamnya diisi dengan daun kedelai untuk mempertahankan kelembaban. Sedangkan kelompok nimfa dan imago yang diperoleh dari lapangan kemudian dimasukkan ke dalam kurungan kain kasa. Di dalam kurungan diisi kacang panjang yang sudah dicuci dengan air agar terbebas dari residu insektisida kimia. Selanjutnya, kelompok telur, nimfa maupun imago dipelihara di dalam laboratorium. Setiap dua hari, pakan diganti dengan kacang panjang yang masih segar dan sebelumnya juga sudah dicuci menggunakan air sebelum dimasukkan ke dalam sangkar.

Masing-masing stadia nimfa yang umurnya sama dimasukkan ke dalam satu sangkar untuk menghindari kompetisi antar umur stadia serangga. Kelompok imago juga dimasukkan ke dalam sangkar yang sama untuk mendapatkan telur-telur yang dihasilkan oleh imago. Kelompok telur yang umurnya sama dikumpulkan menjadi satu ke dalam cawan Petri sebagai perlakuan telur. Umur telur yang digunakan sebagai perlakuan adalah telur yang berumur 0 hari (baru diletakkan imago), telur umur satu hari, dua hari, tiga hari, empat hari, lima hari, enam dan tujuh hari. Sedangkan perlakuan nimfa, dari masing-masing stadia nimfa yang umurnya sama dimasukkan ke dalam milar plastik yang berdiameter $10 \mathrm{~cm}$ dan tinggi $30 \mathrm{~cm}$.Di dalam milar diisi kacang panjang yang sudah dicuci bersih dalam jumlah secukupnya sebagai persediaan pakan nimfa maupun imago sebagai serangga uji.

\section{Perbanyakan Cendawan Entomopatogen $B$.}

bassiana. Isolat cendawan $B$. bassiana yang digunakan sebagai perlakuan adalah koleksi dari Laboratorium Entomologi, Balitkabi dari hasil eksplorasi di Tumpang (Malang) pada tahun 2010 berasal dari serangga Cylas formicarius. Isolat cendawan tersebut telah diuji virulensinya terhadap serangga $C$. formicarius dengan kemampuan membunuh serangga uji 100\% sehingga isolat tersebut dinyatakan sangat virulen.

Isolat cendawan dikulturkan pada media potato dextrose agar (PDA) di dalam cawan Petri. Setelah berumur 14 hari setelah inokulasi (HSI), isolat cendawandiperbanyak pada media beras jagung dengan tujuan untuk memproduksi konidia dalam jumlah yang optimal. Beras jagung sebagai calon media tumbuh sebelumnya dicuci menggunakan air, setelah bersih kemudian direndam di dalam air selama dua jam. Selanjutnya dimasak setengah matang dan dipaparkan di atas nampan, setelah dingin dimasukkan ke dalam kantong plastik kemudian diikat. Media jagung disterilisasi di dalam autoclave pada temperatur 121 ${ }^{0} \mathrm{C}$ selama 30 menit kemudian dibiarkan hingga dingin. Setiap kantong plastik yang berisi media jagung diinokulasi dengan suspensi konidia $B$. bassiana dengan kerapatan konidia $10^{6} / \mathrm{ml}$ sebanyak $10 \mathrm{ml}$ tiap $200 \mathrm{~g}$ media.

Aplikasi Suspensi Konidia Cendawan B. bassiana. Biakan cendawan B. bassiana yang berumur $21 \mathrm{HSI}$, selanjutnya dimasukkan ke dalam erlenmeyer yang dicampur dengan air kemudian dikocok menggunakan shaker selama kurang lebih 30 menit dengan tujuan merontokkan konidia yang terbentuk. Suspensi konidia ditambah Tween 80 sebanyak $3 \mathrm{ml} / \mathrm{l}$ sebagai bahan perata kemudian dikocok agar homogen, selanjutnya disaring menggunakan kain kasa halus untuk memisahkan konidia dengan media biakan cendawan. Jumlah konidia dihitung menggunakan haemocytometer hingga memperoleh kerapatan konidia $10^{8} / \mathrm{ml}$. Aplikasi pada masing-masing perlakuan dilakukan dengan cara menyemprotkan suspensi konidia sebanyak $2 \mathrm{ml}$ tiap unit perlakuan ( 25 butir telur atau 25 ekor nimfa). Setiap dua hari, kacang panjang sebagai pakan nimfa yang diuji diganti dengan kacang panjang yang segar.

Pengamatan. Peubah yang diamati adalah; (1) jumlah telur kepik hijau yang tidak menetas akibat infeksi cendawan B. bassiana, (2) waktu penetasan telur kepik coklat setelah disemprot dengan suspensi konidia $B$. bassiana, (3) jumlah nimfa instar 2 yang mampu hidup dari stadia telur yang terinfeksi cendawan dan (4) mortalitas nimfa setelah disemprot cendawan $B$. bassiana.

Analisis Data. Semua data yang dikumpulkan selanjutnya dianalisis menggunakan program Minitab 14. Apabila terdapat perbedaan yang nyata antar perlakuan, maka dilanjutkan dengan uji jarak berganda (Duncan's multiple range test) pada taraf nyata $\alpha=0.05$.

\section{HASIL DAN PEMBAHASAN}

\section{Toksisitas Cendawan B. bassiana terhadap berbagai Umur Telur Kepik Hijau.} Cendawanentomopatogen $B$. bassiana mampu menginfeksi telur kepik hijau, mulai telur yang baru 
diletakkan imago (0 hari) hingga umur enam hari. Telur kepik hijau yang terinfeksi $B$. bassiana tampak ditumbuhi miselium cendawan yang berwarna putih pada bagian permukaan atas (Gambar 1). Miselium cendawan tumbuh pada permukaan kulit telur (chorion) tiga hari setelah aplikasi. Pada awal infeksi, ditandai dengan miselium tumbuh pada permukaan bagian atas, namun setelah telur berumur tujuh hari maka seluruh permukaan korion dipenuhi oleh miselium yang berwarna putih. Pada perkembangan lebih lanjut koloni miselium $B$. bassiana menyelimuti seluruh permukaan telur, akhirnya telur tidak mampu menetas.

Hasil penelitian menunjukkan bahwa semakin muda umur telur kepik hijau yang disemprot dengan cendawan B. bassiana, semakin rentan terhadap infeksi cendawan sehingga semakin banyak jumlah telur yang tidak mampu menetas. Jumlah telur kepik hijau yang tidak menetas akibat infeksi $B$. bassiana terbanyak terjadi pada perlakuan telur yang baru diletakkan imago (0 hari), yaitu hingga mencapai 96\% (Gambar 2). Meskipun demikian, perlakuan tersebut tidak berbeda nyata dengan perlakuan telur kepik hijau yang berumur satu dan dua hari, yaitu masing-masing $94 \%$ dan $93 \%$. Cendawan B. bassiana juga toksik terhadap telur kepik hijau yang berumur lima dan enam hari, hal ini ditandai dengan jumlah telur yang tidak menetas akibat infeksi cendawan tersebut mencapai $81 \%$. Telur yang berumur lima dan enam hari sebetulnya sudah terbentuk embrio yang akan menetas dalam rentang waktu satu hingga dua hari. Hal ini didasarkan pada penelitian pendahuluan menunjukkan bahwa telur kepik hijau yang normal (tanpa infeksi cendawan) akan menetas pada umur tujuh hari setelah diletakkan imago. Kegagalan penetasan telur pada perlakuan tersebut diduga korion sebagian sudah terbuka pada bagian ujungnya sehingga suspensi konidia yang diaplikasikan langsung menginfeksi embrio.
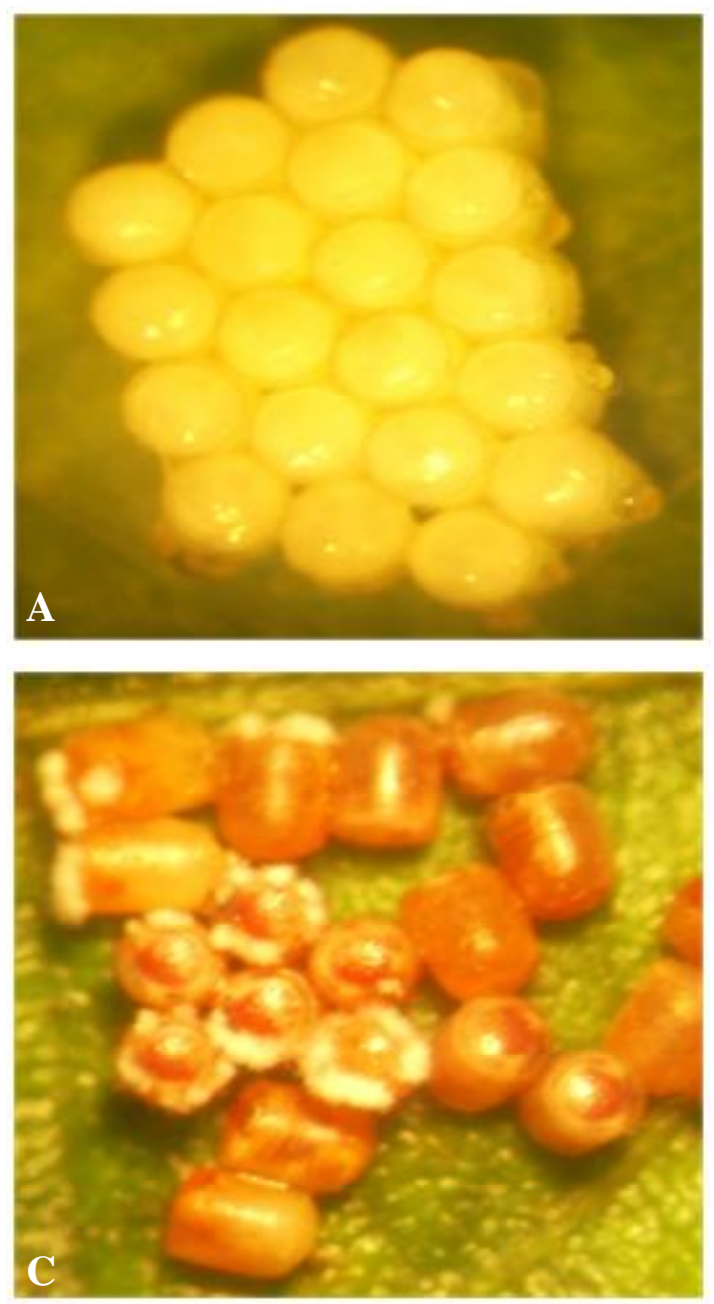
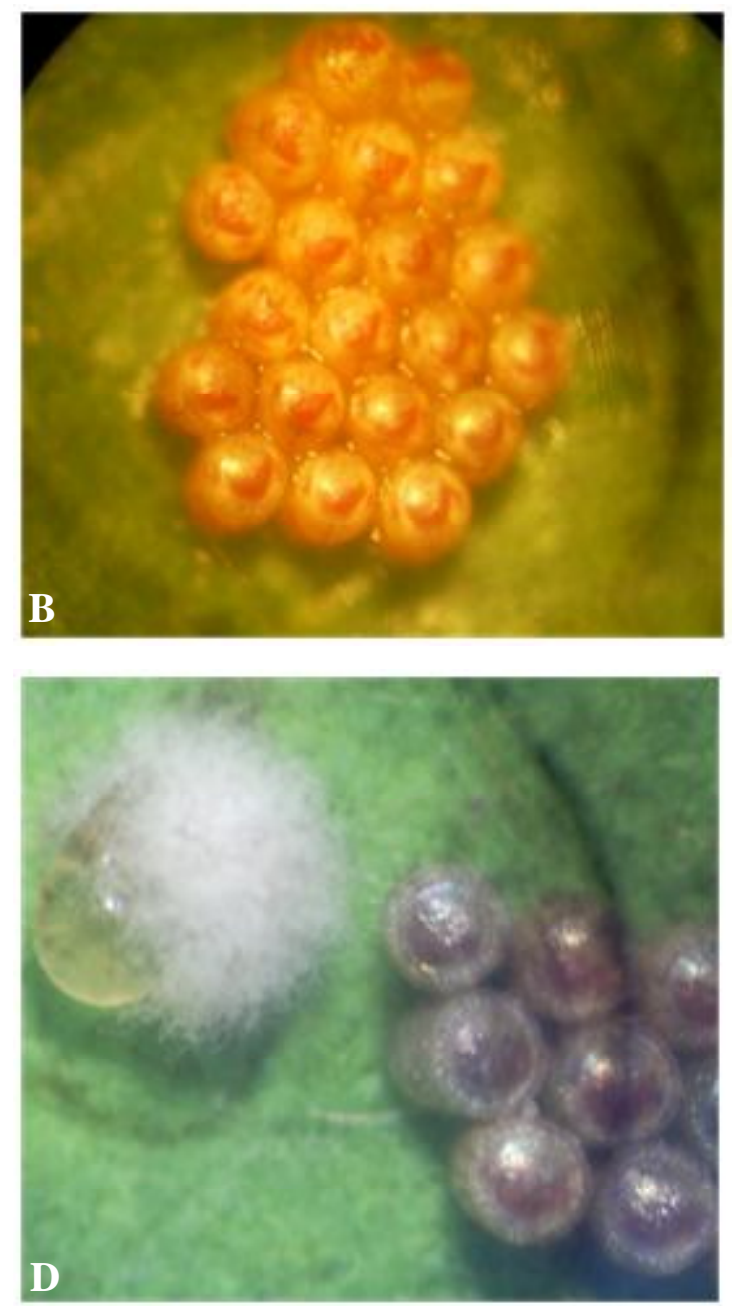

Gambar 1. Kelompok telur kepik hijau normal (A), telur yang disemprot menggunakan cendawan B. bassiana (B), telur terinfeksi $B$. bassiana umur 3 HSA (C), dan telur kepik hijau tidak menetas yang terkolonisasi $B$. bassiana (D). 
Sementara itu, jumlah telur kepik hijau yang tidak menetas terendah terjadi pada perlakuan kontrol (tanpa aplikasi) yaitu $1 \%$.

Cendawan $B$. bassiana sangat toksik terhadap telur kepik hijau karena mampu menggagalkan penetasan telur berkisar $81-96 \%$. Meskipun telur kepik hijau yang terinfeksi cendawan $B$. bassiana masih mampu menetas, namun akhirnya nimfa yang terbentuk juga tidak dapat melangsungkan hidupnya menjadi serangga dewasa. Hal ini disebabkan nimfa I banyak yang mengalami gagal ganti kulit (moulting)sehingga tidak dapat berkembang menjadi nimfa II. Dengan demikian, nimfa yang berhasil menjadi imago sangat rendah sehingga pengendalian kepik hijau pada stadia telur menggunakan cendawan $B$. bassiana dinilai cukup efektif. Hal ini terjadi karena perkembangan populasi hama tersebut di lapangan diprediksi dapat ditekan pada stadia lebih awal sebelum serangga berkembang lebih lanjut sehingga perkembangan serangga selanjutnya menjadi sangat tertekan.

\section{Pengaruh Infeksi Cendawan B. bassiana terhadap} Waktu Penetasan Telur Kepik Hijau. Telur kepik hijau yang terinfeksi cendawan $B$. bassiana pada berbagai umur setelah diletakkan imago mengalami keterlambatan dalam penetasan berkisar antara satu sampai tiga hari. Keterlambatan penetasan telur kepik hijau yang terinfeksi cendawan B.bassiana tidak berbeda nyata dari masing-masing perlakuan umur. Telur yang baru diletakkan imago ( 0 hari) mengalami terlambat menetas selama tiga hari, sedangkan telur yang berumur satu hari akan terlambat menetas selama dua hari (Gambar 3). Telur kepik hijau yang berumur tiga, empat, lima dan enam hari setelah diletakkan imago apabila terinfeksi cendawan $B$. bassiana akan terlambat menetas hanya satu hari. Meskipun keterlambatan penetasan telur kepik hijau yang terinfeksi cendawan B. bassiana tidak berpengaruh nyata dari masingmasing perlakuan umur telur. Namun bergesernya waktu penetasan telur sangat berarti bagi keselamatan biji kedelai apabila terjadi di lapangan. Keadaan ini disebabkan pertumbuhan biji kedelai terus mengalami penuaan, sementara itu perkembangan kepik hijau agak terhambat karena waktu penetasan juga terlambat sehingga perkembangan serangga tidak sinkron dengan perkembangan biji. Dengan demikian, biji yang mengalami pengerasan pada struktur kulit maupun isinya tidak dapat ditusuk oleh stilet kepik hijau karena artikulasi (stilet) belum terbentuk secara optimal.

Hasil penelitian Prayogo (2009) mengindikasikan bahwa telur kepik coklat Riptortus linearis yang terinfeksi cendawan entomopatogen Lecanicillium lecanii (Zare \& Gams) akan mengalami kelambatan menetas sekitar enam hari sehingga ini sangat menguntungkan bagi keselamatan polong kedelai di lapangan. Hal ini disebabkan perkembangan polong

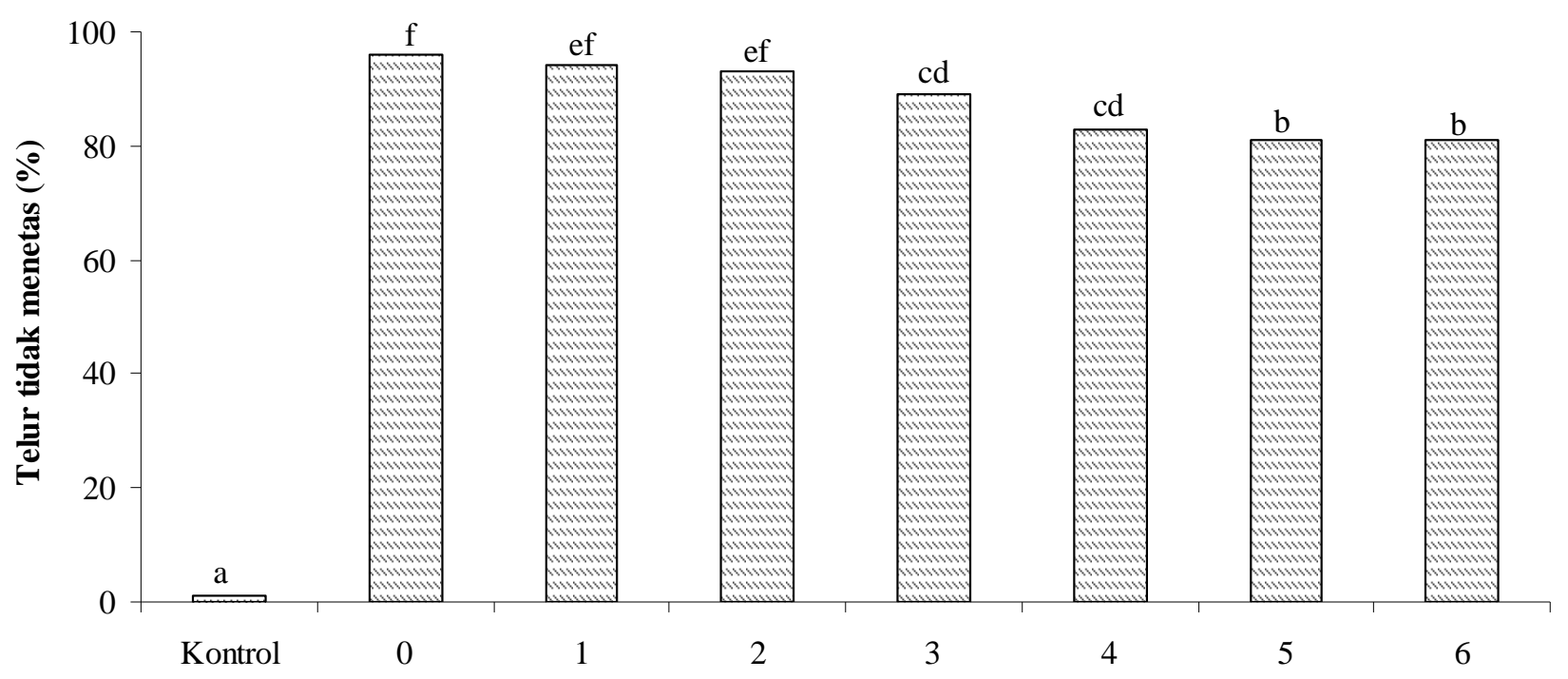

Umur telur kepik hijau setelah diletakkan imago (hari)

Gambar 2. Jumlah telur kepik hijau yang tidak menetas setelah terinfeksi cendawan B. bassiana pada umur yang berbeda.Huruf yang sama diatas bar menunjukkan tidak berbeda nyata berdasar uji Duncan pada $\alpha$ 0,05 . 


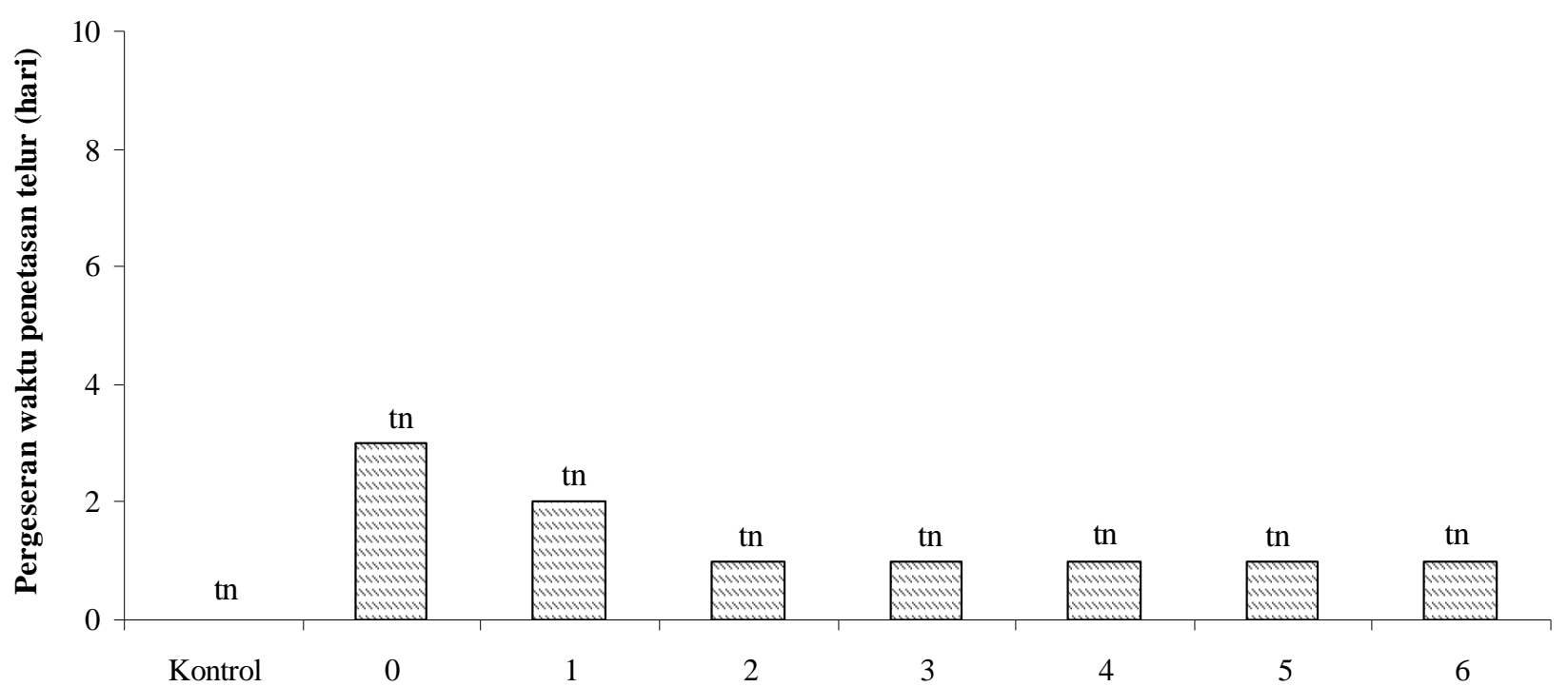

Umur telur kepik hijau setelah diletakkan imago (hari)

Gambar 3. Keterlambatan waktu penetasan telur kepik hijau yang terinfeksi cendawan entomopatogen B. bassiana. tn $=$ tidak nyata.

kedelai tidak sesuai dengan perkembangan nimfa yang akan menjadi imago. Polong kedelai yang sudah mengalami penuaan tidak disukai oleh kepik coklat karena stilet tidak mampu menembus lapisan kulit polong.

\section{Nimfa II Kepik Hijau yang Hidup dari Telur yang}

Terinfeksi B. bassiana. Hasil penelitian menunjukkan bahwa peluang hidup nimfa kepik hijau yang sudah terinfeksi cendawan B. bassiana dari stadia telur sangat rendah. Telur yang terinfeksi cendawan $B$. bassiana dan berhasil menetas menjadi nimfa I, tidak semuanya mampu berhasil berganti kulit (moulting) untuk berkembang menjadi nimfa II. Hal ini disebabkan beberapa serangga mengalami gagal moulting sehingga akhirnya mati dan tidak dapat berkembang menjadi serangga dewasa. Telur yang baru diletakkan imago (0 hari), hanya berpeluang hidup menjadi nimfa II sebesar 2\% (Gambar 4). Sedangkan telur kepik hijau yang berumur satu dan dua hari apabila terinfeksi cendawan B. bassiana hanya berpeluang hidup berkembang menjadi nimfa II dibawah 10\%. Sementara itu, telur kepik hijau yang berumur tiga hingga enam hari yang terinfeksi $B$. bassiana hanya berpeluang menjadi serangga dewasa berkisar $11-14 \%$.

Pengamatan peluang nimfa kepik hijau yang hidup hanya dibatasi pada stadia nimfa II. Hal ini disebabkan kepik hijau merupakan salah satu diantara tiga jenis hama pengisap polong kedelai selain kepik coklat (Riptortus linearis) maupun kepik hijau pucat (Piezodorus hybneri). Dari hasil penelitian Prayogo (2009) menginformasikan bahwa nimfa II kepik coklat yang hidup, berpeluang besar dapat berkembang menjadi serangga dewasa (imago) meskipun pada stadia telur sudah terinfeksi cendawan entomopatogen Lecanicillium lecanii. Hasil penelitian ini mengindikasikan bahwa pengendalian kepik hijau pada stadia telur terutama yang baru diletakkan imago (0 hari) sampai dengan umur dua hari sangat efektif karena serangga dewasa yang hidup hanya berkisar 2-6\%. Aplikasi pada telur yang berumur sampai tujuh hari juga dinilai masih cukup efektif karena populasi serangga dewasa yang hidup hanya di bawah $15 \%$. Dengan demikian, populasi tersebut sangat rendah dan tidak mungkin dapat menyebabkan kerusakan tanaman yang cukup berarti. Aplikasi cendawan pada umur tersebut pada kondisi di lapangan dapat diterapkan pada tanaman kedelai yang berumur 35 hari setelah tanam. Hal ini disebabkan tanaman kedelai pada umur tersebut mulai berbunga dan hama pengisap polong umumnya akan meletakkan telurnya pada tanaman yang sedang berbunga.

Toksisitas CendawanB. bassiana terhadap Nimfa dan Imago Kepik Hijau. Cendawan $B$. bassiana selain toksik terhadap telur kepik hijau, juga mampu menginfeksi dan membunuh stadia nimfa maupun imago. Semakin muda umur nimfa, semakin rentan terhadap infeksi cendawan B. bassiana. Kematian nimfa kepik hijau yang terinfeksi cendawan B. bassiana terjadi pada tiga hari setelah apliaksi (HSA). Pada waktu nimfa mati belum ada tanda-tanda miselium tumbuh pada organ kepik hijau. Sedangkan miselium cendawan B. bassiana 
baru tampak pertama kali pada umur empat hari setelah aplikasi (HSA), yaitu terjadi pada organ artikulasi terutama pada tungkai (Gambar 5) kemudian organ mulut selanjutnya berkembang pada bagian torak. Pada organ artikulasi meliputi persendian tungkai, torak, alat mulut dan ruas-ruas abdomen merupakan daerah yang sangat lentur sehingga lebih mudah dipenetrasi oleh konidia cendawan. Pada bagian-bagian tersebut juga memiliki kandungan kitin yang cukup tinggi sehingga sangat dibutuhkan sebagai sumber makanan bagi cendawan terutama yang memiliki enzim kitinase.Beberapa laporan menyebutkan bahwa sebagian besar cendawan entomopatogen memiliki kandungan enzim kitinase yang cukup besar sehingga sangat toksik dalam mendegradasi dinding integumen serangga (Miranpuri \& Khachatourian 1995; Fang et al. 2005; Lu et al. 2005; Zhu et al. 2008). Enzim kitinase Bbchit1 dan Bbchit2 yang dimiliki oleh $B$. bassiana dilaporkan oleh Fang et

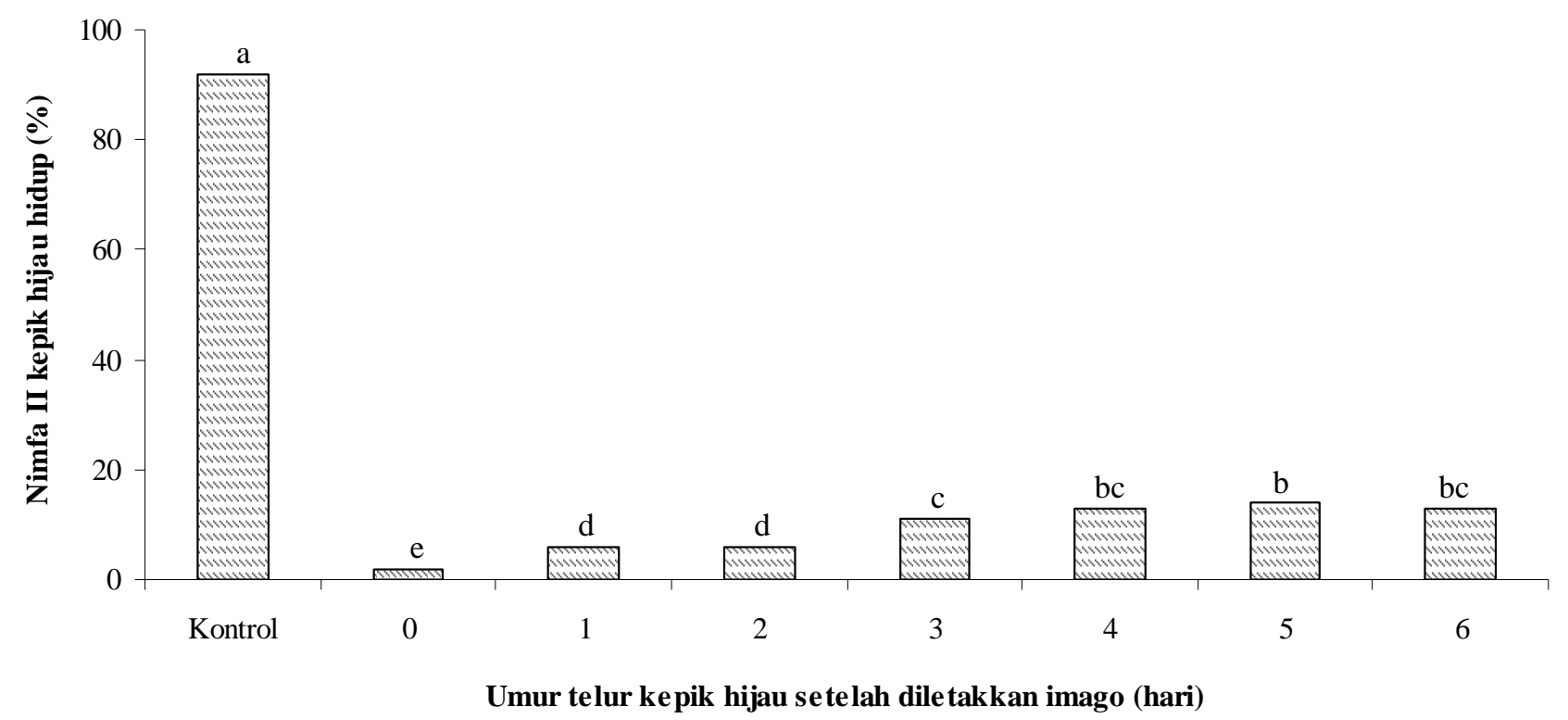

Gambar 4. Persentase peluang nimfa II kepik hijau berkembang menjadi serangga dewasa setelah terinfeksi cendawan B. bassiana pada stadia telur. Huruf yang sama diatas bar menunjukkan tidak berbeda nyata berdasar uji Duncan pada $\alpha 0,05$.
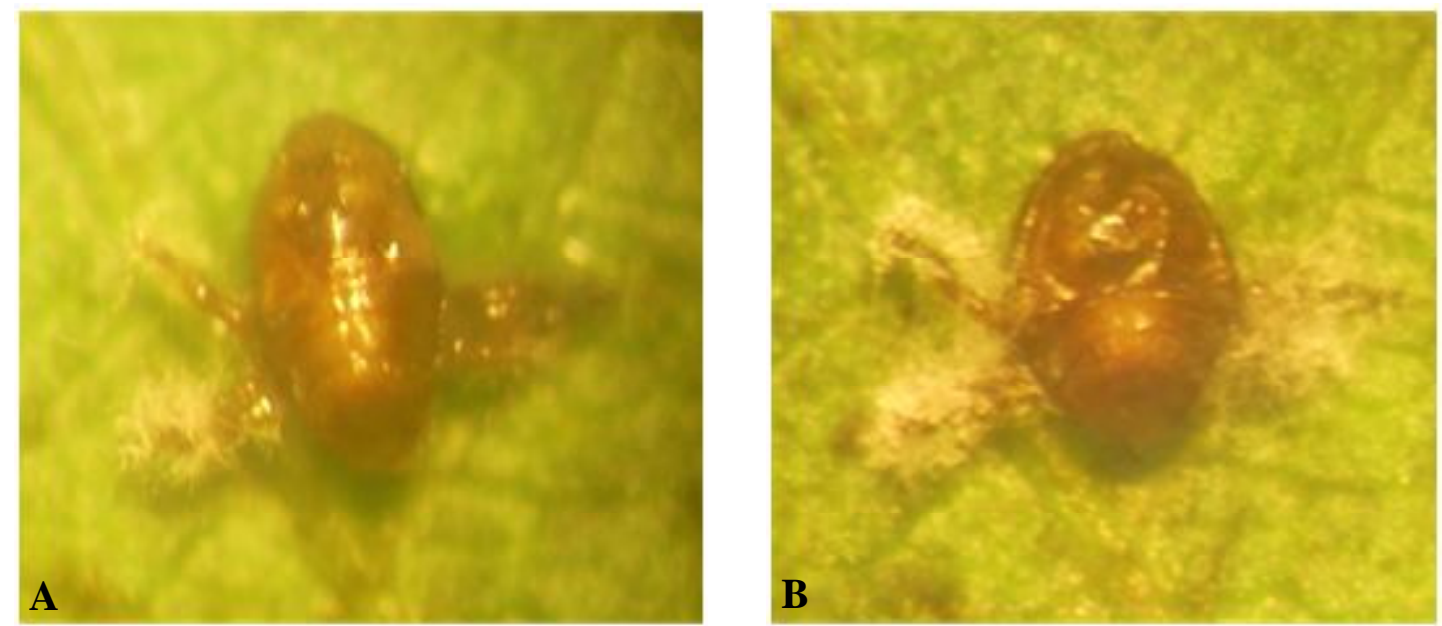

Gambar 5. Tungkai kepik hijau nimfa I yang dikolonisasi oleh cendawan B. bassiana. (A) umur 3 HSA dan (B) umur 4 HSA. 
al. (2005), Holder (2005) dan Fan et al. (2007) sangat toksik terhadap integumen larva serangga dari ordo Lepidoptera.

Hasil penelitian menunjukkan bahwa kematian nimfa maupun imago terjadi pada hari ketiga kemudian kematian serangga semakin hari semakin bertambah banyak, terutama pada perlakuan nimfa I. Pada hari keempat setelah aplikasi tampak kematian nimfa I hingga mencapai 59\% (Tabel 1). Kepik hijau nimfa II juga cukup rentan terhadap infeksi cendawan B. bassiana karena pada hari keempat setelah aplikasi mampu membunuh 46\%. Mortalitas nimfa kepik hijau, semakin hari semakin bertambah banyak terutama pada perlakuan nimfa I dan II. Sementara itu untuk nimfa III, IV, V serta imago pertambahan mortalitas tidak tampak mencolok. Pada tujuh hari setelah aplikasi (HSA), kematian nimfa kepik hijau tertinggi terjadi pada perlakuan nimfa I, yaitu mencapai $86 \%$. Stadia nimfa II kepik hijau juga lebih rentan karena ditandai dengan mortalitas nimfa mencapai $69 \%$.

Tingginya mortalitas nimfa muda kepik hijau akibat infeksi cendawan $B$. bassiana diduga berhubungan dengan struktur integumen tubuh nimfa yang lebih muda lebih lentur karena lapisan lilin (wax) maupun lipid belum optimal sehingga konidia yang sudah berkecambah tidak banyak mengalami hambatan dibandingkan pada stadia nimfa yang lebih tua maupun imago. Lapisan waxpada permukaan integumen serangga merupakan faktor penghalang untuk proses penetrasi konidia cendawan (Lecuona et al. 1997; James 2001). Hasil penelitian James et al. (2003) mengindikasikan bahwa nimfa II kutu kebul Bemisia tabaci sangat toksik terhadap infeksi cendawan $B$. bassiana dibandingkan nimfa III maupun IV. Hal ini disebabkan senyawa lipid merupakan faktor penghambat utama dalam perkecambahan konidia cendawan $B$. bassiana (Buckner et al., 1999; James \& Joronski, 2000; James, 2001). Meskipun Wraight et al. (2000) memaparkan bahwa iklim mikro disekitar integumen serangga yang sangat berpengaruh terhadap perkecambahan konidia dibandingkan faktor lain.

Nimfa kepik hijau yang mati terinfeksi $B$. bassiana setelah tujuh hari tampak terjadi kolonisasi miselium cendawan yang berwarna putih menyelimuti seluruh tubuh sehingga kelihatan berbentuk seperti mumi (Gambar 6). Kolonisasi pada tubuh serangga tersebut berisi kumpulan miselium dan kumpulan konidia sebagai organ infektif untuk distribusi atau penyebaran patogen pada suatu lokasi. Semakin cepat kolonisasi terjadi pada tubuh inang, semakin banyak produksi konidia sebagai organ infektif yang dihasilkan oleh cendawan sebagai agens hayati. Dengan demikian, peluang terjadi distribusi cendawan dari serangga mati ke inang baru (serangga sehat) semakin cepat sehingga lebih cepat dalam menyebabkan epizooti dan akhirnya peledakan hama pada suatu lokasi sulit akan terjadi (Verghese \& Sreedevi, 2006; Ganga-Visalakshy et al., 2010; Rios-Velasco et $a l ., 2010)$. Distribusi cendawan entomopatogen terjadi secara horizontal, yaitu dari serangga sakit ke serangga inang yang sehat, semakin banyak konidia yang dihasilkan semakin besar pula terjadi distribusi patogen dan semakin cepat terjadi epizooti (Knudsen \& Schotzko, 1999; Krreutz et al., 2004; Vickers et al., 2004).

Dari hasil penelitian ini menginformasikan bahwa nimfa I dan II lebih rentan dibandingkan dengan stadia nimfa III, IV, V maupun imago. Hasil penelitian James et al. (2003) yang menguji efikasi cendawan $B$. bassiana terhadap berbagai stadia $B$. tabaci juga diperoleh hasil yang serupa, yaitu nimfa II $B$. tabaci lebih rentan terhadap infeksi $B$. bassiana dibandingkan stadia nimfa III maupun IV. Oleh karena itu, untuk menekan perkembangan populasi kepik hijau dianjurkan aplikasi menggunakan cendawan $B$. bassiana pada stadia nimfa muda maupun stadia telur. Keberhasilan pengendalian pada stadia tersebut, disebabkan telur merupakan stadia yang belum mampu bergerak sehingga lebih mudah dibidik, apalagi telur diletakkan oleh imago secara bergerombol dan tersusun secara teratur di atas

Tabel 1. Mortalitas nimfa kepik hijau setelah disemprot menggunakan suspensi konidia B. bassiana

\begin{tabular}{lccccccc}
\hline \multirow{2}{*}{ Stadia kepik hijau } & \multicolumn{7}{c}{ Mortalitas nimfa kepik hijau pada hari ke...n (HS A) } \\
\cline { 2 - 8 } & 1 & 2 & 3 & 4 & 5 & 6 & 7 \\
\hline Nimfa I & 0 & 0 & 38 & 59 & 76 & 84 & 86 \\
Nimfa II & 0 & 0 & 32 & 46 & 50 & 66 & 70 \\
Nimfa III & 0 & 0 & 15 & 16 & 16 & 16 & 16 \\
Nimfa IV & 0 & 0 & 7 & 7 & 7 & 7 & 7 \\
Nimfa V & 0 & 0 & 3 & 3 & 3 & 3 & 3 \\
Imago & 0 & 0 & 5 & 10 & 15 & 16 & 18 \\
\hline
\end{tabular}



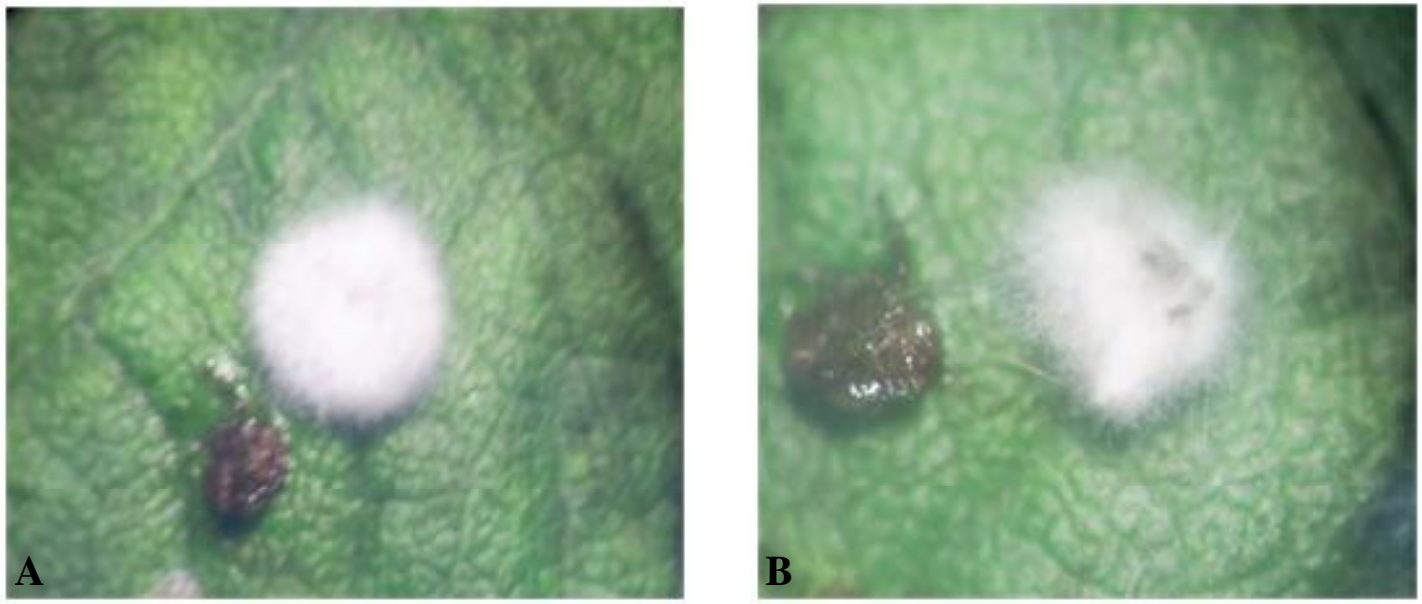

Gambar 6. Nimfa kepik hijau yang dikolonisasi miselium cendawan B. bassiana yang berbentuk seperti mumi. (A) Nimfa I dan (B) Nimfa II.

permukaan daun kedelai. Dengan demikian peluang suspensi konidia yang disemprotkan hampir $100 \%$ berhasil mengenai serangga sasaran.

Stadia telur merupakan stadia awal dan belum mampu menyebabkan kerusakan pada polong maupun biji kedelai. Selain itu, stadia telur belum dapat dikendalikan digagalkan proses penetasannya oleh satu jenis senyawa insektisida kimia. Hasil penelitian ini menegaskan bahwa cendawan B.bassiana mampu bersifat ovisidal terhadap telur kepik hijau. Sementara keberhasilan pengendalian pada stadia nimfa muda karena pada umur tersebut mobilitas nimfa sangat rendah sehingga sangat rentan terhadap faktor lingkungan terutama aplikasi cendawan entomopatogen. Stadia nimfa I dan II belum begitu merusak polong maupun biji kedelai, karena pada stadia tersebut serangga hanya mengkonsumsi kandungan air yang terdapat pada organ polong maupun yang ada organ tanaman lainnya.

\section{SIMPULAN}

Dari hasil penelitian ini dapat disimpulkan bahwa cendawan $B$. bassiana bersifat ovisidal dan sangat patogenik sehingga toksik dan mampu menggagalkan penetasan telur kepik hijau hingga mencapai $90 \%$. Stadia telur,nimfa I dan II kepik hijau lebih rentan terhadap infeksi cendawan $B$. bassiana dibandingkan stadia nimfa III, IV, V maupun imago. Cendawan B. bassiana berpeluang besar dapat digunakan sebagai salah satu agens hayati untuk pengendalian kepik hijau terutama stadia telur, karena telur diletakkan imago secara berkelompok sehingga lebih mudah dibidik. Cara dan dan waktu aplikasi cendawan B. bassiana yang efektif dan efisien untuk pengendalian kepik hijau di lapangan masih perlu diverifikasi lebih lanjut.

\section{DAFTAR PUSTAKA}

Buckner JS, Hagen MM, \& Nelson DR. 1999. The composition of the cuticular lipids from nymphs exuviae of the silverleaf whitefly Bemisia argentifolii. Com. Biochem. Physiol. 124:201207.

Cloyd RA \& Bethke JA. 2010. Impact of neonicotinoid insecticides on natural enemies in greenhouse and interiorscape environments. Pest Manag. Sci. 67:3-9.

Correra-Ferreira BS \& Azevedo J. 2002. Soybean seed damage by different species of stink bugs. Agric. \& Forest Entomol. 4:145-152.

Dhuyo AR \& Ahmad S. 2007. Evaluation of fungus Beauveria bassiana (Bals.) infectivity to the larger grain borer Prostephanus truncates (Horn.). Pak. Entomol. 29(2):77-83.

Echegaray FJ. 2009. Environmental effect of insecticides on non target predator and parasitoid insects. [Thesis]. RoyalRoadsUniversity, Francisco. http:/ /dspace.royalroads.ca/docs /bitstream/handle/ $10170 / 130 /$ echegaray, Francisco. pdf?sequence=1. [21 Sep 2011].

Ehler LE. 2002. An evaluation of some natural enemies of Nezara viridula in Northern California. Biocontr. 47(3):309-325. 
El-Husseini MM, Draz KAA, El-Aw MAM \& Askar SIS. 2006. Some biological and morphological aspects of Trisolcus basalis Wollaston (Hymenoptera: Scelionidae) an egg parasitoid of Nezara viridula (L.) (Hemiptera: Pentantomidae). Egypt J. Biol. Pest. Contr. 16(2):111-114.

Emfinger K, Leonard BR, Gore J, \& Cook D. 2001. Insecticide toxicity to Southern green stink bug Nezara viridula (L.) and brown Eushistus servus (Say.) In: D.D. Hardee and E. Burris (Eds.). Proceedings, Beltwide Cotton Confferences Anaheim, California 7-12 January 2001, National Cotton Council Memphis, TN.pp:1159-1161.

Fan Y, Fang W, Guo S, Pei X, Zhang Y, Xiao Y, Li D, Jin K, Bidochka MJ, \&Pei Y. 2007. Increase insect virulence in Beauveria bassiana strains overexpressing an engineered chitinase. Appl. \& Environ. Microbiol.73(1):295-302.

Fang WG, Leng B, Xiao YH, \& Pei Y. 2005. Cloning of Beauveria bassiana chitinase gene Bbchitl and its application to improve fungal strain virulence. Appl. Environ. Microb. 71:363-370.

Fortes P, Magro SR, Panizzi AR, \& Parra JRP. 2006. Development of a dry articial diet for Nezara viridula (L.) and Euschistus heros (Fabricius). (Hemiptera: Pentatomidae). Neotrop Entomol. 35(5):567-572.

Ganga-Visalakshy PN, Mani M, Krishnamoorthy A, \& Gopalakrishna-Pillai K. 2010. Epizootics of Entomophthora sp. on mango inflorescence hopper Idioscopus nitidulus (Walker). Biol Contr. 24(3):274-275.

Gonzalez JOW \& Ferrero AA. 2008. Tbale of life and fecundity by Nezara viridula var.Smaragdula (Hemiptera: Pentatomidae) feed on Phaseolus vulgaris L. (Fabaceae) fruits. IDESIA (Chile) 26(1):9-13.

Greene JK, Capps C, Lorenz GM, Young SY \& Norton C. 2003. Evaluation of insecticides for control of insect pests on soybean. Arthropod Manag Test 28F. 97.

Holder DJ. 2005. Adhesion Properties and Cell Surface Characteristics of the Entomopathogenic Fungus Beauveria bassiana: a Link Between Morphology and Virulence. [Desertasi]. University of Florida.
James RR \& Joronski S. 2000. Effect of low viability on infectivity of Beauveria bassiana conidia toward the silverleaf whitefly. J Invertebr. Pathol. 76:227-228.

James JJ. 2001. Effects of exogenous nutrients on conidial germination and virulence against the silverleaf whitefly for two hyphomycetes. $J$. Invertebr. Pathol. 77:99-107.

James RR, Buckner JS, \& Freeman TP. 2003. Cuticular lipids and silverleaf whitefly stages affect conidial germination of Beauveria bassiana and Paecilomyces fumosoroseus. J. Invertebr. Pathol. 84:67-74.

Jones VP \& Westcot D. 2002. The effect of seasonal, changes on Nezara viridula (L.) (Hemiptera: Pentantomidae) and Trissolcus basalis (Wollaston) (Hymenoptera: Scelionidae) in Hawai. Biol. Contr. 23(2):115-120.

Kim DS, Brooks DJ \& Riedl H. 2006. Lethal and sublethal effects of abamectin, spinosad, methoxyfenozide and acetamiprid on the predaceous plant bug Deraeocoris brevis in the laboratory. Biol. Contr. 51:465-484.

Knight KMM \& Gurr GM. 2007. Review of Nezara viridula $(\mathrm{L}$.$) management strategies and potential$ for IPM in field crops with emphasis on Australia. Crop Prot. 26(1):1-10.

Knudsen GR \& Schotzko DJ. 1999. Spatial simulation of epizootics caused by Beauveria bassiana in Russian wheat aphid populations. Biol. Contr. 16:318-328.

Krreutz J, Zimmermann G \& Vaupel O. 2004. Horizontal transmission of the entomopathogenic fungus Beauveria bassiana among the spruce bark beetle Ips typographus (Coleoptera: Scolytidae) in the laboratory and under field conditions. Biocontr. Sci. Technol. 14(8):837-848.

Lecuona R, Clement JL, Riba G, Joulie C, \&Juarez P. 1997. Spore germination and hyphal growth of Beauveria spp. on insect lipids. J. Econ. Entomol. 89:119-123.

Lozano-Gutierrez J \& Espana-Luna MP. 2008. Pathogenicity of Beauveria bassiana (Deuteromycotina: Hyphomycetes) against the white grub Laniifera cyclades (Lepidoptera: Pyralidae0 under field and greenhouse conditions. Florida Entomol. 91(4):664-669. 
Lu ZX, Laroche A \& Huang HC. 2005. Isolation and characterization of chitinase from Verticillium lecanii. Can. J. Microbiol. 51:1045-1055.

Mau RFL \& Kessing JL. 2007. Nezara viridula (Linnaeus). Crop Knowledge Master. http:// www.extento.hawai.edu/kbase/crop/nezara.htm [20 Sep2011].

Miranpuri GH \& Khachatourian GG. 1995. Comparative virulence of different isolates of Beauveria bassiana and Verticillium lecanii against Colorado potato beetle Leptinotarsa decemlineata (Say.). J. Insect. Sci. 8(2):160166.

Noda T \& Kamano S. 2002. Artificial rearing of Nezara viridula (L.) and $N$. antennata (Hemiptera: Pentatomidae) with semi-solid meridic diets. Appl. Entomol. Zool.37(1):43-50.

Panizzi AR, Mcpherson JE, James DG, Javahery M, \& Mcpherson RM. 2000a. Stink bugs (Pentatomidae) In: Schaefer, C.W., A.R. Panizzi, (eds.). Heteropera of Economy Importance. Boca Raton, Florida, USA: CRC Press. p:432434.

Panizzi AR, Parra JRP, Santos CH, \& Carvalho DR. 2000b. Rearing the souther green stink bug using artificial dry diet and artificial plant. Pesqu Agropec. Bras. 35:1709-1715.

Prayogo Y. 2009. Kajian cendawan entomopatogen Lecanicillium lecanii (Zimm.) (Viegas) Zare \& Gams sebagai agens hayati untuk mengendalikan telur hama pengisap polong kedelai Riptortus linearis (F.) (Hemiptera: Alydidae). [Disertasi]. Departemen Proteksi Tanaman. Sekolah Pascasarjana. Institut Pertanian Bogor.

Rios-Velasco C, Cerna-Chavez E, Pena SS, \& GallegesMorales G. 2010. Natural epizootic of the entomopathogenic fungus Nomuraea rileyi (Farlow) Samson infecting Spodoptera frugiperda (Lepidoptera: Noctuidae) in Coahvila Mexico. The Journal of Res on The Lepidptera 43:7-8

Rogers MA, Krischik VA, \& Martin LA. 2007. Effect of soil application of imidacloprid on survival of adult green lacewing Chrysoperla carnea (Neuroptera: Chrysopidae) used for biological control in greenhouse. Biol. Contr. 42:172-177.
Studebaker GE \& Kring TJ. 2003. Effects of insecticides on Orius insidiosus (Hemiptera: Anthocoridae) measured by field, greenhouse, and Petridish bioassays. FI Entomol. 86:178-185.

Tamuli AK \& Gurusubramanium G. 2011. Entomopathogenicity of white muscardine fungus Beauveria bassiana (Bals.) Vuill. (Deuteromycotina: Hyphomycetes) (BBFF-135) agaisnt Odontotermes (Rambur) (Isoptera: Termitidae). J. of Sci. \& Technol.: Biological \& Environ. Sci. 7(1):118-125.

Tillman PG. 2006. Susceptibility of pest Nezara viridula (Hemiptera: Pentatomidae) and parasitoid Trichopoda pennipes (Diptera: Tachinidae) to selected insecticides. Biol. \& Microbial. Contr. 99(3):648-657.

Trizelia \& Nurdin F. 2010. Virulence of entomopathogenic fungus Beauveria bassiana isolates to Crocidolomia pavonana (F.) (Lepidoptera: Crambidae). Agrivita 32(2):254262.

VergheseA \& Sreedevi K. 2006. Epizootics of an entomopathogenic fungus Entomophthora aphid Hoggman on the pomegranate aphid Punicaepasserine (Homoptera: Aphididae). Commun. Agric. Appl. Biol. Sci. 71(4):47-52.

Vickers RA, Furlong MJ, White A, \& Pell JK. 2004. Initiation of fungal epizootics in diamonback moth populations whithin a large field cage: proof of concept for auto-dissemination. Entomol. Et Exp. Appl. 111(1):7-17.

Vivan LM \& Panizi AR. 2005. Nymphal and adult performance of genetically determined types of Nezara viridula (L.) (Hemiptera: Pentatomidae) under temperature and photoperiodic conditions. Neotrop. Entomol. 34:911-915.

Vivan LM \& Panizzi AR. 2006. Geographical distribution of genetically determined types of Nezara viridula (L.) (Hemiptera: Pentatomidae) in Brazil. Neotrop. Entomol. 35(2):175-181.

Willrich MM, Temple J, Goble RH, \& Leonard BR. 2003. Evaluation of insecticides for control of nymph and adult southern green stink bugs. Arthropod Manag Tests 28F. 77. 
Wraight SP, Carruthers RI, Jaronski ST, Bradley CA, Garza CJ, \& Gailani-Wraight S. 2000. Evaluation of the entomopathogenic fungi Beauveria bassiana and Paecilomyces fumosoroseus for microbial control of the silverleaf whitefly Bemisia argentifolii. Biol. Contr. 17:203-217.
Zhu Y, Pan J, Qiu J, \& Guan X. 2008. Isolation and characterization of a chitinase gene from entomopathogenic fungus Verticillium lecanii. Braz. J. of Microbiol. 39:314-320. 